\title{
Beyond Excessive Risk-Taking Behavior in Village- Owned Enterprises
}

\author{
M Elfan Kaukab ${ }^{1 *}$, Romandhon ${ }^{1}$, Agus Putranto ${ }^{1}$, Susanti $^{1}$ \\ ${ }^{1}$ Faculty of Economics, Universitas Sains Al-Quran Jawa Tengah, Wonosobo, Indonesia \\ *Corresponding author. Email: elfan@unsiq.ac.id
}

\begin{abstract}
Without adequate capital to be a reserved fund for the failure of a business, a risk-taking entrepreneur might fall into bankruptcy and suffer trauma to restart the business. Unfortunately, literature sees that risk-taking behavior is a positive characteristic of an entrepreneur and makes it a linear variable in which the higher the risk is taken, the better the entrepreneur's orientation is. This research aims to explore the entrepreneurs' excessive risk-taking behavior from the goal-setting perspective to have a better understanding of entrepreneurs' reactions to the environment. To achieve the goal, we collected data from 383 Village-Owned Enterprises (BUMDes) leaders in Central Java. The quantitative analysis reveals that risk-taking behaviors vary based on environmental uncertainty, organizational commitment, and entrepreneurs' creativity. This shows that consideration should be given to the environment factor (environmental uncertainty) and individual factors (commitment and creativity) related to excessive risk-taking in designing village business strategy.
\end{abstract}

Keywords: excessive risk-taking behavior, goal setting, environmental uncertainty, commitment,

creativity

\section{INTRODUCTION}

A large number of Village-Owned Enterprises (BUMDes) in a regency/city reflects that society and village empowerment are high. Until 2019, there are 42,000 BUMDes all over Indonesia, around $50 \%$ of the whole villages [1]. In 2014-2017, the government distributed funds to villages that were used to establish 14,770 BUMDes around Indonesia to boost economic activities and increase society's life quality [2]. However, many of those BUMDes fell into bankruptcy in only months after their establishment, allegedly because they were founded without a good plan, aimed businesses without the market, and followed currently-developing trends [3]. Moreover, many BUMDes inefficiently manage their budget and spend it on comparative studies advancing recreation instead of knowledge [4].

BUMDes' ability to lift society's welfare depends on its human resources' quality, including the quality of its leader. At this moment, BUMDes exhibit excessive risk-taking behavior because they make development without a proper plan in business. It happens since the managers are confused with high environmental uncertainty. They are unsure of which part to manage to make BUMDes successful.

Another problem related to BUMDes is their leaders' commitment. BUMDes establishment and development require total commitment to providing stability during early hard times. The commitment will lead the existing creativity to turn into productivity. Thus, as the government expects, BUMDes can become a creative economy source for rural society.
Among the many BUMDes, there are some prominent ones. BUMDes Karya Jaya Abadi, for example, is considered to be active, innovative, and bold in taking steps to buy palm oil directly from the community member [5]. One interesting thing about this case is that the BUMDes is creative and bold in taking a risk.

There have been debates in the literature on whether risktaking behavior is expected in business development [6], [7]. Only a few companies have gained success owing to their boldness, while others face extreme problems due to it. Excessive risk-taking behavior can give severe effects on a company. Thus, formulating appropriate steps to maintain a risk in its portion can be carried out by understanding the factors of excessive-risk taking behavior.

The current studies focus on three questions. First, whether perceived environmental uncertainty by BUMDes leaders generates excessive risk-taking behavior. Second, if the organizations leaders' commitment steers their excessive risk-taking behavior. And third, whether BUMDes leaders' creativity affects excessive risk-taking behavior. This research aims to answer these questions.

The goal-setting theory holds that optimal performance should be reached when its aim is specifically defined (in terms of clear), and it is difficult (in terms of requires quite an amount of effort) [8]. The aim is also self-determined, which if reached, proves that the person is capable, worthy, and deserving [9]. The goal-setting theory states that in reaching the goal, a person needs to identify, be committed, and fight for it while at the same time get feedback on the goal [10]. There are four mechanisms affecting performance, one of which is strategical mechanism that encourage people to find or develop strategies to reach the goal [11]. 
Based on the goal-setting theory, risk-taking behavior is a manifestation of commitment. Note that goal-setting theory maintains that the goal to be reached should be of specific, self-defined or explicitly agreed upon, and most importantly, it has reasonable difficulty [12]. The goal is reachable, but not so easy. This means that the goal bears risks. If the goal is too easy, then it does not have any risk, while goal-setting theory states this will not be motivating. It is the risky goal that motivates [13] and even encourages someone to take even the excessive risk [14]. Studies suggest that people who tend to take risks are individuals with an orientation to reach a certain goal [15]. The uncertain environmental challenges a manager to face a high difficulty level, which should nurture the goal-setting potential. Meanwhile, creativity is a capital to reach the goal by determining an effective strategy. He/she will have the self-determination to be a creative and innovative individual when the goal is reached. Thus, the goal-setting theory is the proper theoretical framework in this research.

\subsection{Perceived Environmental Uncertainty}

Perceived environmental uncertainty is a person's perception of environmental changes that affect a company's performance. This elevates the possibilities of elements or connections in a system to be the expired day today [16]. In other words, environmental uncertainty is a perception of the company's dubious external environment [17]. Environmental uncertainty comes from many sources such as political instability, government policies, macroeconomy, social, and natural [18].

\subsection{Excessive risk-taking behavior}

Risk-taking is defined as "aiming participation in form of behavior that involves negative consequences potential or social, monetary, and/or interpersonal loss, and perceived positive consequences or advantages over it" [19]. Thus, excessive risk-taking behavior means an elevation of negative and positive consequence potentials of the behavior.

Personality theory regards risk-taking behavior as an attributive trait of a certain personality [20]. However, the theory of planned behavior [21] states that behavior is not merely an individual's attitude because it is also influenced by society's or the closest people's subjective norms and ease in behavior.

Studies have been conducted to examine the determinants of risk-taking behavior. Some have proven that personality contributes to risk-taking behavior along with other factors. Czernecka et al found that risk-taking behavior is affected by duty context and additional incentive [22]. Research also showed that financial freedom, professional norms, and willingness to cheat or break rules to gain personal advantages are the determinant of excessive risk-taking behavior [23]. Yip et al identified emotional intelligence's role in reducing excessive risk-taking behavior based on anxiety [24].

In the business context, Yip et al maintained that an individual will evaluate an uncertainty $\mathrm{s} / \mathrm{he}$ faces when dealing with risky decisions [24]. It implies that perceived environmental uncertainty influences the excessive risktaking behavior. A review by Jahanshahi and Brem revealed that there is a bigger risk-taking tendency in an unstable environment and changes related to are hardly predictable [25]. Matsuno in his research stated that perceived environmental uncertainty increases the needs and opportunities of an organization to take the risk, which later will be compensated with bigger rewards [26]. Therefore, environmental uncertainty aspect relates to the excessive risk-taking behavior and the hypothesis of this research is formulated

H1: Perceived environmental uncertainty positively affects the excessive risk-taking behavior.

\subsection{Organizational Commitment}

Organizational commitment can be defined as "a relative power to identify an individual's involvement in an organizational and the willingness to make efforts to stay in the organizational" [27]. It is a psychological readiness and an internal passion to work in an organizational [28]. Organizational commitment relates to employees' psychological attachment to their organizational [29]. It is known to be derived from perceived working autonomy, personality, adaptability, organizational stress, organizational structure, organizational support, employees' involvement, interpersonal relationship, work satisfaction, role clarity, internal marketing, transformational leadership behavior, education qualification, and job characteristics [30]-[35].

Organizational commitment corresponds to the excessive risk-taking behavior since a committed individual will make all the efforts necessary to stay in the organizational [36]. The commitment also lifts up employees' performance [37], while the efforts of boosting the performance are also risky. The point is that the employees feel responsible for organizational success and make all the efforts to ensure it. Thus, risk-taking is a consequence of high organizational commitment [38]. Based on this, we propose the hypothesis H2: Organizational commitment is positively associated with excessive risk-taking behavior.

\subsection{Creativity}

Creativity is the creation of something new [39]. It is a generation of new useful ideas by employees in their various jobs [40]. Research has identified that various social networks possessed by an individual can boost his/her creativity in problem-solving [41]. In its turn, creativity significantly affects the entrepreneurial attitude and intention [42].

Entrepreneurial performance might highly depend on the courage in taking risks [43], [44]. Hence, risk-taking courage is also an indicator of entrepreneurship orientation [45]. However, the theoretical and empirical relationship between creativity and excessive risk-taking behavior is not clear. Shen et al showed that the existing relationship is insignificant because risk-taking does not relate to the divergent way of thinking, which is one of the 
characteristics of creativity [46]. On the other hand, Tyagi et al found that creativity in general (biographic creativity) positively affects social risk-taking [47]. Addressing the issue, Shen et al suspected that different cultures and methods yield different relationships [46]. We argue that creativity has positive effects on an individual's action that can be in the form of excessive risk-taking. It is because creativity guarantees a person to face risks, which in turn encourages him/her to take bigger risks. Therefore, the relationship between creativity and excessive risk-taking behavior is positive. Based on that, we hypothesize:

H3: Creativity positively associates to excessive risk-taking behavior

\section{METHOD}

This research was carried out in Central Java from 2 September - 18 September 2019. Central Java is chosen since this province has the largest number of villages in Indonesia. There are 2.511 BUMDes in Central Java [48]. With 29 regencies, the average number of BUMDes in each one is 86. A cross-sectional design is applied. Samples are taken using the Slovin formula with confidence lapse $95 \%$ on the number of BUMDes samples, yielding 345 BUMDes. Considering the $10 \%$ non-responsive level, the final samples are 383. This number can adequately be accommodated by five regencies. Therefore, the researchers randomly selected five regencies in Central Java and distributed questionnaires in their villages with BUMDes.

a. Data Collection Procedures

A respondent's self-filled structured questionnaire is used to obtain the data. The instruments are developed based on several works of literature.

b. Instrument

The perceived environmental uncertainty scale is adopted from Bouzourine [49]. Organizational commitment item is adapted from Spanuth and Wald [50], while creativity item is adopted from Huang et al [51]. All items are answered on a five-item Likert scale with response options range from 1 (strongly disagree) to 5 (strongly agree). Risk-taking is formatted in a single item developed by Wang and Poutziouris in five options ranging from 1 (very daring in taking risk) to 5 (very not dare in taking risk) [52]. As a control to avoid social desirability bias, the Arnaud's desirability social item is used [53].

c. 2.3. Data Analysis Procedures

The data are checked for their completeness and then exported to be analyzed in a statistic software. They are explored using descriptive statistics by looking at the mean and standard deviation. Multiple linear regression is used to test the hypothesis proposed in this research after controlling social desirability. Variables' connection with $\mathrm{p} \leq 0.10$ is regarded as statistically significant. Besides, a multicollinear assumption of linear assumption, general method bias, and reliability of the previous data are also examined prior to the conclusion.

\section{RESULTS AND DISCUSSION}

All of the research variables undergo bias test and reliability test processes prior to further analysis. The general method bias test is examined by analyzing exploratory factors and yielding the first factor of $37.09 \%$, which is lower than the $50 \%$ minimum limit. Thus, the general method bias is absence.

Environmental uncertainty reliability is 0.711 in three items. The organizational commitment's reliability is 0.858 in six items while creativity's reliability is 0.928 in two items. Social desirability's reliability is 0.985 in two items. Collinearity statistics show that there is no problem with tolerance that is always lower than 1,0 and VIF that is under 4.0.

The descriptive statistics of research variables are displayed in Table 1. It should be noted that risk-taking behavior is classified as low in the research samples. Out of the five options, only 1 (very not dare in taking risks) and 2 (not dare in taking risks) were chosen by the samples.

Table 1 Summary Statistics

\begin{tabular}{|lccccc|}
\hline \multicolumn{1}{|c}{ Variable } & Obs. & Mean & Sdv. & Min & Max \\
\hline Environmental uncertainty & 383 & 3.57 & 0.59 & 2.0 & 5.0 \\
\hline $\begin{array}{l}\text { Organizational } \\
\text { commitment }\end{array}$ & 383 & 3.99 & 0.83 & 3.0 & 5.0 \\
\hline Creativity & 383 & 3.36 & 0.89 & 1.5 & 5.0 \\
\hline Social desirability & 383 & 1.68 & 0.46 & 1.0 & 2.0 \\
\hline Risk-taking behavior & 383 & 1.79 & 0.41 & 1.0 & 2.0 \\
\hline
\end{tabular}

Table 2 summarizes the regression result in risk-taking behavior. The first three rows show the hypothesized variables. The coefficient of environmental uncertainty is negative, which means that the less certain the environment is. the more unlikely the respondents will take risks $(-0.145$ $\mathrm{p}<0.001)$. The organizational commitment and creativity significantly affect the risk-taking behavior (organizational commitment $=0.076 \mathrm{p}<0.10$; creativity $=0.077 \mathrm{p}<0.05)$.

Table 2 Effects of Independent Variables on Excessive Risk-Taking Behavior

\begin{tabular}{|lrrc|}
\hline \multicolumn{1}{|c}{ Variable } & \multicolumn{1}{c}{ B } & Std. Error & Sig. \\
\hline Environmental uncertainty & -0.145 & 0.044 & 0.001 \\
\hline Organizational commitment & 0.076 & 0.044 & 0.080 \\
\hline Creativity & 0.077 & 0.027 & 0.004 \\
\hline Social desirability & -0.446 & 0.073 & 0.000 \\
\hline F & 21.70 & & 0.000 \\
\hline $\mathrm{R}^{2}$ & 0.187 & & \\
\hline
\end{tabular}

Our study reveals that environmental uncertainty decreases the risk-taking behavior, contrary to the research's hypothesis 1 . The results show that entrepreneurs are willing to take risks only in a certain environment. This finding contradicts previous research such as Yip et al [24], Jahanshahi and Brem [25], and Matsuno [26]. The village actually takes to advantage out of the stable business environment by developing business innovations. While on the other hand, the village initiates mediocre businesses in an unstable business environment. This finding could explain by the tendency that the manager of village-owned enterprises to take risk-averse behavior when uncertainty in environment high. They are not behaving like independent 
[2] J. Widodo and J. Kalla, "Report on Four Years of Joko Widodo - Jusuf Kalla Government (Laporan 4 Tahun Pemerintahan Joko Widodo - Jusuf Kalla),” Jakarta, 2018.

[3] A. Resti, "Early Death of Village Owned Enterprises, What are the Causes and the Solutions? (Tren 'Mati Suri' Usaha BUMDes, Apa Penyebab dan Solusi Utamanya ?)," Bumdes.id, 2019. [Online]. Available: https://bumdes.id/2019/07/tren-mati-suriusaha-bumdes-apa-penyebab-dan-solusi- utamanya/. [Accessed: 31-Aug-2019].

[4] Berdesa, "Four Things that Should be Abandoned by Village Owned Enterprises (4 Hal yang Harus Dihindari BUMDes)," Berdesa, 2017. [Online]. Available: http://www.berdesa.com/4-hal-harusdihindari-bumdes/. [Accessed: 31-Aug-2019].

[5] Berdesa, "Learning from Village Owned Enterprises which Successful in Empowering Society (Belajar Dari BUMDes-BUMDes Yang Terbukti Berhasil Mensejahtrakan Masyarakat)," Berdesa, 2018. [Online]. Available: http://www.berdesa.com/belajar-daribumdes-bumdes-yang-terbukti-berhasilmensejahtrakan-masyarakat/. [Accessed: 31-Aug2019].

[6] J. Choi, "Entrepreneurial Risk-Taking, Young Firm Dynamics, and Aggregate Implications," 2017.

[7] P. Patel, M. Li, M. del C. Triana, and H. D. Park, "Pay dispersion among the top management team and outside directors: Its impact on firm risk and firm performance," Hum. Resour. Manage., vol. 57, pp. 177-192, 2018.

[8] G. F. Tondello and H. Premsukh, "A Theory of Gamification Principles Through Goal-Setting Theory," in Hawaii International Conference on System Sciences, 2018, vol. 51.

[9] C. Belciug, C. Franklin, K. W. Bolton, C. Jordan, and P. Lehmann, "Effects of goal commitment and solution building on the completion rates for a juvenile diversion program," Crim. Justice Behav., vol. 43, no. 7, pp. 923-936, 2016.

[10] R. A. Kambarami, N. N. Mbuya, D. Pelletier, and D. Fundira, "Performance Differ by Task in a MultiTasked Setting," Glob. Heal. Sci. Pract., vol. 4, no. 2, pp. 238-250, 2016.

[11] M. K. Robison, "Regulating Mind-Wandering and Sustained Attention with Goal-Setting, Feedback, and Incentives," University of Oregon, 2018. 
[12] A. Pepper and J. Gore, "Behavioral agency theory : new foundations for theorizing about executive compensation," J. Manage., vol. 41, no. 4, pp. 10451068, 2015.

[13] S. Oh and H. Baek, "Successful Crowdfunding : Focusing on Social Interaction and Goal Achievement Motivations," Inf. Syst. Res., vol. 12, pp. 141-161, 2016.

[14] M. J. Neubert and B. Dyck, "Developing Sustainable Management Theory: Goal-Setting Theory based on Virtue," Manag. Decis., vol. 54, no. 2, pp. 304-320, 2016.

[15] J. Han and Q. Lu, “A Correlation Study among Achievement Motivation, Goal-Setting and L2 Learning Strategy in EFL Context," English Lang. Teach., vol. 11, no. 2, pp. 5-14, 2018.

[16] Y. Snihur and J. Tarzijan, "Managing Complexity in a Multi-Business-Model Organization," Long Range Plann., vol. 51, no. 1, pp. 50-63, 2018.

[17] M. Kreye, "Relational uncertainty in service dyads," Int. J. Oper. Prod. Manag., vol. 37, no. 3, pp. 363-381, 2017.

[18] E. Derayati, “The Impact of Relative Institutional Challenge on the Process of Firms'

Internationalization," Concordia University, 2016.

[19] A. W. Green, “An exploration of the emotional experience of BASE jumping," Massey University, 2017.

[20] G. Breivik, T. S. Sand, and A. M. Sookermany, "Risk-Taking and Sensation Seeking in Military Contexts : A Literature Review," SAGE Open, vol. 9, no. 1, p. 2158244018824498, 2019.

[21] I. Ajzen, "The theory of planned behavior," Organizational Behav. Hum. Decis. Process., vol. 50, pp. 179-211, 1991.

[22] K. Czernecka, J. Fryt, A. La Torre, and T. Smolen, "Many face(t)s of young people's risk-taking: Individual and situational determinants," Curr. Issues Personal. Psychol., vol. 6, no. 2, pp. 112-121, 2018.

[23] A. Cohn, E. Fehr, and M. A. Maréchal, "Do Professional Norms in the Banking Industry Favor Risk-taking?," Rev. Financ. Stud., vol. 30, no. 11, pp. 3801-3823, 2017.

[24] J. A. Yip, D. H. Stein, S. Côté, D. R. Carney, D. H. Stein, and D. R. Carney, "Emotion Follow Your Gut? Emotional Intelligence Moderates the Association
Between Physiologically Measured Somatic Markers and Risk-Taking," Emotion, vol. Advance on, 2019.

[25] A. A. Jahanshahi and A. Brem, "Entrepreneurs in post-sanctions Iran : Innovation or imitation under conditions of perceived environmental uncertainty?," Asia Pacific J. Manag., 2018.

[26] K. Matsuno, “The Effects of Environmental Uncertainty and Entrepreneurial Proclivity on Market Orientation Process and Growth Momentum," Kindai Manag. Rev., vol. 3, pp. 36-48, 2015.

[27] M. Kaplan and A. Kaplan, "The Relationship between Organizational Commitment and Work Performance : a Case of Industrial Enterprises," J. Econ. Soc. Dev., vol. 5, no. 1, pp. 46-50, 2018.

[28] S. M. Diab and M. T. Ajlouni, "The Influence of Training on Employee's Performance, Organizational Commitment, and Quality of Medical Services at Jordanian Private Hospitals,” Int. J. Bus. Manag., vol. 10, no. 2, pp. 117-127, 2015.

[29] Z. Inanlou and J. Ahn, "The Effect Of Organizational Culture On Employee Commitment : A Mediating Role Of Human Resource Development In Korean Firms," J. Appl. Bus. Res., vol. 33, no. 1, pp. 87-94, 2017.

[30] B. Israel, W. Kifle, D. Tigist, and W. Fantahun, "Primary Health Care : Open Access Organizational Commitment and its Predictors among Nurses Working in Jimma University Specialized Teaching Hospital, Southwest Ethiopia," Prim. Heal. Care, vol. 7, no. 1, pp. $1-8,2017$.

[31] R. P. Guay, D. Choi, I.-S. Oh, M. S. Mitchell, M. K. Mount, and K.-H. Shin, "Why People Harm the Organization and Its Members: Relationships among Personality, Organizational Commitment, and Workplace Deviance," Hum. Perform., vol. 29, no. 1, pp. 1-15, 2016.

[32] S. Jiang, E. G. Lambert, X. Jin, D. Xiang, M. Shi, and D. Zhang, "Correlates of Organizational Commitment Among Community Correctional Officers in China," Prison J., vol. 98, no. 1, pp. 60-82, 2018.

[33] J. T. P. Lin and N. C. L. Ping, "Perceived Job Autonomy and Employee Engagement as Predictors of Organizational Commitment," Undergrad. J. Psychol., vol. 29, no. 1, pp. 1-16, 2016.

[34] A. E. Green, C. R. Dishop, and G. A. Aarons, "Organizational Stress as Moderator of Relationship Between Mental Health Provider Adaptability and 
[45] M. Stuetzer, D. Audretsch, M. Obschonka, S. D. Gosling, J. P. Rentfrow, and J. Potter,

"Entrepreneurship Culture, Knowledge Spillovers, and the Growth of Regions," Reg. Stud., vol. 52, no. 5, pp. 603-618, 2018.

Eskandari, "The effect of internal marketing, organizational commitment and organizational citizenship behaviors on market orientation (case study : employees of Tehran chain stores)," Int. J. Humanit. Cult. Stud., pp. 82-100, 2016.

[36] M. Farrukh, W. Y. Chong, S. Mansori, and S. R. Ramzani, "Intrapreneurial behaviour : the role of organizational commitment," World Journal Entrep. Manag. Sustain. Dev., vol. 13, no. 3, pp. 243-256, 2017.

[37] C.-H. Ko and S.-N. Jeng, "Mobile Technology Adopted In Hotel Sales,” Int. J. Organ. Innov., vol. 8, no. 2, pp. 172-186, 2015.

[38] D. Kim and J. Jung, "Cultural attributes and risk perception : the moderating role of different types of research and development," J. Risk Res., vol. 9877, no. July, pp. 1-16, 2017.

[39] J. A. Antoncic, B. Antoncic, and Z. Li, "Creativity of the Entrepreneur, Intrapreneurship, and the Growth of Small and Medium-Sized Enterprises: Evidence from China," Chinese Bus. Rev., vol. 17, no. 7, pp. 336-341, 2018.

[40] A. Srivastava and S. Yun, "Psychological Contract Breach and Creativity : Examination of Linkages," Labor Relations, vol. 12, no. 29, pp. 1-23, 2018.

[41] R. Y. J. Chua, "Innovating at Cultural Crossroads : How Multicultural Social Networks Promote Ideas Flow and Creativity," J. Manage., vol. 44, no. 3, pp. 1119-1146, 2018.

[42] A. Kusmintarti, A. Asdani, and N. I. Riwajanti, "The relationship between creativity, entrepreneurial attitude and entrepreneurial intention (case study on the students of State Polytechnic Malang), ' Int. J. Trade Glob. Mark., vol. 10, no. 1, pp. 28-36, 2017.

[43] S. Venkataraman, "The Distinctive Domain of Entrepreneurship Research," in Seminal Ideas for the Next Twenty-Five Years of Advances, Emerald Group Publishing Ltd., 2019, pp. 5-20.

[44] M. Baas, S. Koch, B. A. Nijstad, and C. K. W. De Dreu, "Conceiving Creativity : The Nature and Consequences of Laypeople's Beliefs About the Realization of Creativity," Psychol. Aesthetics, Creat. Arts, vol. 9, no. 3, pp. 340-354, 2015.
[46] W. Shen, B. Hommel, Y. Yuan, C. Liu, and W. Zhang, "Risk-taking and creativity : Convergent, but not divergent thinking is better in low-risk takers," Creat. Res. J., vol. 30, no. 2, pp. 224-231, 2018.

[47] V. Tyagi, Y. Hanoch, S. D. Hall, M. Runco, and S. L. Denham, "The Risky Side of Creativity : Domain Specific Risk Taking in Creative Individuals," Front. Psychol., vol. 8, p. Article 145, 2017.

[48] Jateng Today, "There are 2,511 Village Owned Entreprises in Central Java, not all have been seriously worked on (Ada 2.511 BUMDes di Jateng, Belum Semua Digarap Serius)," Jateng Today, 2019. [Online]. Available: https://jatengtoday.com/ada-22-000-bumdesdi-jateng-belum-semua-digarap- serius-21716. [Accessed: 31-Aug-2019].

[49] A. Bouzourine, "Contingency Factors And Strategic Management Accoljnting Usage In The Algerian Medium-Sized Enterprises," Universiti Utara Malaysia, 2017.

[50] T. Spanuth and A. Wald, "Understanding the antecedents of organizational commitment in the context of temporary organizations : An empirical study," Scand. J. Manag., vol. 33, no. 3, pp. 129-138, 2017.

[51] Z. Huang, S. Chang, and J. Wu, "A Study on the Influence of Team Members ' Social Media Interaction Perception on Employee Creativity,” Am. J. Ind. Bus. Manag., vol. 7, pp. 1209-1228, 2017.

[52] Y. Wang and P. Poutziouris, "Entrepreneurial risk taking: empirical evidence from UK family firms," Int. J. Entrep. Behav. Res., vol. 16, no. 5, pp. 370-388, 2010.

[53] A. Arnaud, "Conceptualizing and Measuring Ethical Work Climate: Development and Validation of the Ethical Climate Index (Eci).," Acad. Manag. Annu. Meet. Proc., vol. 8, no. 1, pp. E1-E6, 2006.

[54] D. Kahneman and A. Tversky, "Prospect Theory: An Analysis of Decision under Risk," Econometrica, vol. 47, no. 2, pp. 263-292, 1979. 